\title{
Efficiency of Outsourcing in the Public Sector in the Czech Republic
}

\author{
Juraj Nemec \\ Department of Public Economics \\ ESF Masaryk University \\ Brno, Czech Republic \\ e-mail: juraj.nemec@econ.muni.cz
}

\author{
Beata Mikusova Merickova \\ Department of Public Economics \\ EF Matej Bel University \\ Banska Bystrica, Slovakia \\ e-mail: beata.merickova@umb.sk
}

\author{
Marketa Sumpikova \\ Department of University of Finance and Administration \\ Prague, Czech Republic \\ e-mail: sumpik@seznam.cz
}

\begin{abstract}
Outsourcing internal services to private for-profit and non-profit firms is one of the most prevalent types of alternative service-delivering arrangements. The relevant literature proposes that outsourcing may, but need not, improve cost-effectiveness and the quality of service delivery. The efficiency of outsourcing is determined by policy and management capacities, resources and experience in public sector of specific country. This paper seeks to analyze the efficiency of outsourcing in the Czech public sector by using the multicriteria analysis (MBVI method, used to construct composite efficiency scores). The study uses a quantitative approach to investigate the research question and analyzes the originally collected survey data from own research. The results are slightly complicated - our analysis does not show one uniform trend, cannot answer if outsourcing is better solution as compared to internal production. However, such findings are in line with international experience, indicating that the success of outsourcing depends on many internal and external factors and cannot be universalised.
\end{abstract}

Keywords - outsourcing; public sector; efficiency; Czech Republic

\section{INTRODUCTION}

The relevant literature (see below) suggests that if and only if the outsourcing is properly implemented, it may (but need not) improve cost-effectiveness and quality of provision of internal services in public organisations (we differentiate between contracting of local public services and outsourcing of internal services in our research). In this paper, we attempt to measure efficiency of outsourcing in the Czech Republic on a non-representative sample of public organisations by multicriteria analysis - the MBVI method, used to construct composite efficiency scores. Based on our findings, we formulate conclusions and research implications.

\section{OUTSOURCING IN THE PUBLIC SECTOR: BRIEF THEORETICAL INTRODUCTION}

Outsourcing represents the situation of delegating originally own activities of an economic subject to an external supplier. Graever [1] defines the following purposes of outsourcing: organizational, process, financial, incomes, decreasing costs and employment. Other authors [2, 3, 4, 5] add also other purposes for outsourcing, for example the focus on core business and resources, cost restructuring, quality improvements, access to intellectual property and wider experience and knowledge, access to operational best practice that would be too difficult or time-consuming to develop in-house, access to a larger talent pool and a sustainable source of skills, in particular in science and engineering, or capacity and risk management.

Outsourcing in the public sector was first introduced in larger scale as a part of New Public Management (NPM) initiatives during the last two decades of the previous century. Its theoretical base - the issue of privatization and contractualisation in the public sector - was investigated by many authors $[6,7,8,9]$. NPM aims at continuous increase in public expenditure efficiency, continual improvements in public services quality, implementation of professional management tools in the public sector, emphasis on devolution and delegation, emphasis on audit and inspection and, last but not least, the plurality system of ownership forms in delivering of public service and emphasis on contracts and market.

Outsourcing begins with the "organizational decision to make or buy a good or service" [10, p. 176]. As such, it is a fundamental decision faced by both public and private sector organizations. "To make or buy?" is a question faced by public organizations when considering how public services should be delivered. Public organizations must decide whether to produce goods and services internally or acquire them from external sources.

To put outsourcing in perspective, it is necessary to consider pros and cons of internal and external forms of delivery. The possible positive results of outsourcing in the public sector are very similar to these in the private sector, but the main focus is on optimizing costs and quality.

An important element of outsourcing is the process involved in establishing and maintaining a legal contractual 
relationship with a private firm. According to Shetterly [11, p. 23], this process occurs in three phases: pre-solicitation, contractor selection and contract management. Two problems occur when the action and information of the private partner are not directly observable by the public partner: moral hazard or the problem of hidden action and adverse selection or the problem of hidden information [12]. Moral hazard occurs because the behaviour of the private partner is imperfectly controlled. When behaviour is imperfectly controlled, it creates a situation where either shirking in performance of duties or inappropriate actions by the private partner adversely impacts the goals of the public partner. In the adverse selection problem, the private firm has some information that is not shared with the public sector organization and uses the information to make decisions that affect the public organization. In many cases, the public sector organization does not have enough information for ex ante evaluation of the private offers. Another crucial issue for success of outsourcing is transactions costs that may overweight direct costs savings from switch to external delivery [13].

From all above, it is apparent that outsourcing may - but need not - improve the performance of the public sector. The final outcome depends on local conditions, including the implementing body's capacity to execute the contracting process.

\section{OUtSOURCING In PUBliC ORGANIZATIONS: CZECH REPUBLIC: SCALE AND RESULTS}

The existing research into contractualisation in the delivery of public services in the Czech Republic and neighbouring countries [14, 15, 16, 17] focuses mainly on contracting local public services. There are much less data on outsourcing of internal services in public organisations. The results presented by existing studies indicate numerous problems in contracting. Therefore, we decided to take first steps in analysing the outsourcing of internal services and this article presents the first current set of data.

Our research is realised on the non-representative sample of 42 Czech public organisations delivering different kinds of public services (Table 1). The analysis focuses on service delivery arrangements of selected internal services in public organisations: cleaning, catering, maintenance, IT, transport, and security.

TABLE I. RESEARCH SAMPLE

\begin{tabular}{|l|r|r|r|r|r|r|}
\hline Public & \multicolumn{7}{|c|}{ Internal service } \\
\cline { 2 - 7 } $\begin{array}{c}\text { organi } \\
\text { zation } \\
\text { in: }\end{array}$ & $\begin{array}{r}\text { Clea } \\
\text { ning }\end{array}$ & $\begin{array}{c}\text { Cater } \\
\text { ing }\end{array}$ & $\begin{array}{c}\text { Maint } \\
\text { enanc } \\
\text { e }\end{array}$ & \multicolumn{1}{|c|}{ IT } & Transport & Security \\
\hline Culture & 14 & 11 & 4 & 12 & 10 & 8 \\
\hline $\begin{array}{l}\text { Social } \\
\text { service }\end{array}$ & 8 & 6 & 6 & 8 & 5 & 4 \\
\hline $\begin{array}{l}\text { Educati } \\
\text { on }\end{array}$ & 20 & 17 & 15 & 20 & 5 & 12 \\
\hline Sum & 42 & 34 & 25 & 40 & 20 & 24 \\
\hline
\end{tabular}

Source: own research
As the first step, we provide data about the scale of outsourcing (for our sample). As indicated by the Table 2, the outsourcing is not prevalent, but frequent internal service delivery arrangement in Czech public organizations.

TABLE II. SCALE OF OUTSOURCING IN THE CZECH REPUBLIC

\begin{tabular}{|l|r|r|r|c|c|c|}
\hline \multirow{2}{*}{$\begin{array}{c}\text { Public } \\
\text { organi } \\
\text { zation } \\
\text { in: }\end{array}$} & \multicolumn{6}{|c|}{ The proportion of internal delivery arrangements for } \\
\cline { 2 - 7 } & $\begin{array}{c}\text { Clea } \\
\text { ning }\end{array}$ & $\begin{array}{c}\text { Cater } \\
\text { ing }\end{array}$ & $\begin{array}{c}\text { Maint } \\
\text { enanc } \\
\text { e }\end{array}$ & IT & Transport & Security \\
\hline Culture & 57.1 & 72.7 & 0.0 & 83.3 & 40.0 & 87.5 \\
\hline $\begin{array}{l}\text { Social } \\
\text { service }\end{array}$ & 50.0 & 16.6 & 0.0 & 75.0 & 0.0 & 50.0 \\
\hline $\begin{array}{l}\text { Educati } \\
\text { on }\end{array}$ & 5.0 & 35.3 & 26.7 & 30.0 & 20.0 & 66.7 \\
\hline Sum & 37.4 & 41.5 & 8.9 & 62.8 & 20.0 & 68.1 \\
\hline
\end{tabular}

Source: own research

The technical efficiency of outsourcing can be measured by parametric and non-parametric evaluation methods, which permit simultaneous comparison of the inputs and outputs of an outsourcing and in-house service production and produce concise indicators of efficiency. Considering the nature of the public organisations involved in our analysis, we decided to use a particular non-parametric method, the Method of best values of indicators (MBVI), which is encountering growing consensus as a powerful tool to measure public organisations productivity because it allows the heterogeneity of delivered outputs to be taken into account $[18,19,20]$.

MBVI is one of the nonparametric multidimensional approaches to the evaluation of efficiency of Decision Making Units (DMU) based on a weighted sum algorithm. Here we designated the service delivery method as a DMU. This method makes it possible to express the efficiency of evaluated DMUs, considering many indicators, measured in different units.

The method is simple to apply and easy to interpret. Following Zizka [21, pp. 146-147], we consider m service delivery alternatives $\mathrm{Ai}(\mathrm{i}=1 \ldots \mathrm{m})$, and $\mathrm{n}$ indicators of evaluation $\mathrm{Kj}(\mathrm{j}=1 \ldots \mathrm{n})$. When we assign empirical values for all delivery alternatives and evaluation indicators, we obtain the evaluation matrix $\mathrm{X}$. The most efficient service delivery alternative is the option with maximal score $E$. The efficiency of other options is given proportionally to Alternative Emax.

In the analysis focused on technical efficiency of outsourcing in public organisations, we have chosen three indicators of evaluation as efficiency benchmarks:

- The costs of service delivery per employee.

- The unit costs of service delivery (Table 3).

- The quality of service. 
TABLE III. UNIT COST INDICATORS FOR SELECTED INTERNAL SERVICES

\begin{tabular}{|l|l|}
\hline \multicolumn{1}{|c|}{ Service } & Calculation unit \\
\hline Cleaning & \multicolumn{1}{c|}{$\mathrm{m}^{2}$} \\
\hline Catering & Number of users \\
\hline Maintenance & Number of actions \\
\hline IT & Number of actions \\
\hline Transport & Average km yearly \\
\hline Security & $\mathrm{m}^{2}$ of protected area \\
\hline
\end{tabular}

Source: own research

As for internal services in public organisations, we have to acknowledge that measuring the quality of a service is generally much more difficult than measuring the quality of a good. Service quality may be identified in terms of performance characteristics, but their assessment may require subjective judgments. It can be measured through user satisfaction, but this is subjective because individual opinions on what constitutes a high standard of service quality may vary from one user to another. The best way to cope with this problem is to follow the research methodology of several existing studies in the area of service quality evaluating in public sector $[22,23]$. Data on service quality were provided by users, employees of different public organisations, or using a questionnaire. The samples are nonrepresentative (total 420 persons were interviewed), so we admit that our summary data are partly preliminary.

Employees evaluated internal service quality using the following scale:

- Absolutely satisfied

$$
\begin{aligned}
& 100 \% \\
& 80 \%
\end{aligned}
$$$$
\text { - More satisfied than unsatisfied } \quad 60 \%
$$$$
\text { - Unsatisfied } 20 \%
$$$$
\text { - Absolutely unsatisfied } 0 \%
$$

To calculate MBVI, we assigned weights (vj) to the indicators (Table 4). To set the weights, we used Saaty's method [24] with inputs from a panel of experts on outsourcing.

TABLE IV. WEIGHTS (VJ) FOR INDICATORS

\begin{tabular}{|l|r|}
\hline Indicator & vj \% \\
\hline Unit costs of service delivery per employee & 30 \\
\hline $\begin{array}{l}\text { Unit costs of service delivery per } \\
\text { service outcome }\end{array}$ & 30 \\
\hline Quality of service & 40 \\
\hline$\Sigma$ & 100 \\
\hline
\end{tabular}

Source: own research

Table 5 provides our results - the measurement of efficiency of outsourcing on our sample of 42 Czech public organisations. The maximum combined score is 100 points, with higher scores indicating greater efficiency.

\begin{tabular}{|c|c|c|c|c|c|c|c|}
\hline \multirow{2}{*}{$\begin{array}{c}\text { Public } \\
\text { organi } \\
\text { zation } \\
\text { in: }\end{array}$} & \multicolumn{7}{|c|}{$\begin{array}{c}\text { The proportion of internal delivery arrangements for } \\
\text { selected services }(\%)\end{array}$} \\
\hline & $\begin{array}{l}\text { Deliv } \\
\text { ery } \\
\text { form }\end{array}$ & $\begin{array}{l}\text { Clea } \\
\text { ning }\end{array}$ & $\begin{array}{l}\text { Cate } \\
\text { ring }\end{array}$ & $\begin{array}{c}\text { Main } \\
\text { tena } \\
\text { nce }\end{array}$ & IT & $\begin{array}{l}\text { Tran } \\
\text { sport }\end{array}$ & $\begin{array}{c}\text { Secu } \\
\text { rity }\end{array}$ \\
\hline \multirow{2}{*}{ Culture } & Int. & 98.42 & 90.04 & $(-)$ & 91.49 & 70.00 & 100.0 \\
\hline & Ext. & 100.0 & 100.0 & $(-)$ & 100.0 & 100.0 & 56.30 \\
\hline \multirow{2}{*}{$\begin{array}{l}\text { Social } \\
\text { service }\end{array}$} & Int. & 84.50 & 100.0 & $(-)$ & 84.05 & $(-)$ & 79.91 \\
\hline & Ext. & 100.0 & 52.40 & $(-)$ & 100.0 & $(-)$ & 100.0 \\
\hline \multirow{2}{*}{$\begin{array}{l}\text { Educati } \\
\text { on }\end{array}$} & Int. & 94.20 & 100.0 & 100,0 & 73.10 & 74.70 & 59.44 \\
\hline & Ext. & 100.0 & 80.20 & 96,96 & 100.0 & 100.0 & 100.0 \\
\hline
\end{tabular}

TABLE V. SCALE OF OUTSOURCING IN THE CZECH REPUBlic

Source: own research

In-house production proves to be the better solution in 4 cases, while outsourcing is preferable in 11 cases. Overall average results favour outsourcing. However, we need to be aware of several methodological problems related to our research. The core problems are the reliability of the data, and the reliability of the research methods.

First, we are fully aware of the limited reliability of data collected from municipalities. Their cost monitoring is not sophisticated. They do not use accrual accounting and so cannot recognize the real cost of service delivery. With service in-house delivery, the reported service costs only cover direct costs, and so are likely to be too low. In fact, there is no full cost accounting at the local self-government level in Czech Republic, and this devalues the cost data on service in-house delivery.

The methodological reliability issue is that the results could be sensitive to the assumed weights. Although we did not conduct a full sensitivity analysis, we have confidence in the experience of the expert panel involved in Saaty's method.

Leaving aside the above mentioned limitations, the data collected seem to insinuate that outsourcing of internal services is more effective than in-house production. Consequently, the outsourcing should be the primary delivery arrangement for these services. However, as the problems with methodology and data clearly reveal, such conclusions are not quite evident, and there is no doubt more research is still needed (this is currently realised by our team.)

\section{CONCLUSIONS}

Most of the developed countries have implemented new principles of public sector reform - new approaches to the management of the public sector. A major feature of the new public management is the introduction of market type mechanisms to the running of public service organizations: the marketization of the service financed from public sources. The marketization aims at a continuous increase in public expenditure efficiency, continual improvements in services quality, the implementation of the professional management 
tools in the public sector. However, in many cases the introduction of the NPM tools does not produce the expected results and even creates perverse effects. One of these tools is the outsourcing in public sector, which may improve costeffectiveness and the quality of delivery and to some extent also expenditure control. To put outsourcing in perspective, it is necessary to consider not only the expected benefits, but also the risks related to outsourcing in public sector - for example, the Czech Republic still features no well-developed competitive market or public management.

The paper analyzed the efficiency of outsourcing in the Czech public sector using the MBVI method, which permits comparison of the inputs and outputs of the outsourcing and in-house service production. Overall average results of efficiency measurement favour outsourcing, however, we cannot fully rely on such findings. The more appropriate conclusions would be that the results of outsourcing between public organisations vary and depend not so much on the organisational form of delivery, but on other factors, especially the quality of decision-making and contract management on the level of public organisations. We already continue our research to obtain more comprehensive and representative information on this.

\section{ACKNOWLEDGMENT}

The research is supported by the Czech Grant Agency GACR under the contract P403/12/0366 Identification and evaluation of region specific factors determining outcomes of reforms based on NPM - the case of CEE.

\section{REFERENCES}

[1] M. F. Greaver, Strategic Outsourcing: A Structured Approach to Outsourcing Decisions and Initiatives. American Managment Association, 1999.

[2] P. J. Cooper, Governing by Contract. Washington D.S.: CQ Press, 2003.

[3] J. A. Kay and D. J. Thompson, "Privatisation: a policy in search the rationale", Economic Journal, vol. 96, 1/1986, pp. 18 - 32.

[4] J. Øvretveit, Purchasing for Health. London: Oxford University Press, 1995.

[5] G. K. Yarrow and P. Jasinski, Privatization: Critical Perspectives on the World Economy. New York: Taylor \& Francis, 1996

[6] J. Cullis and P. Jones, Public Finance and Public Choice. London: McGraw - HILL BOOK CO, 1992.

[7] J. E. Lane, New Public Management. London: Rutledge Taylor Francis Group, 2000
[8] Ch. Pollit and G. Bouckaert, Public Management Reform a Comparative Analysis. London: Oxford University Press, 2000.

[9] I. Maly, "Verejne statky a verejne poskytovane statky", Politická ekonomie, vol. 46, 1998, pp. 861-868.

[10] J. Prager, "Contracting Out Government Services: Lessons from the Private Sector", Public Administration Review, vol. 54, 1994, no. 2, pp. 176-184.

[11] D. R. Shetterly, "The influence of contract designs on contractor performance", Public Performance \& Management Review, vol. 24, 1998, no. 1, pp. 53-68.

[12] K. J. Arrow, "The Economics of Agency". In: J. W. Pratt and R. J. Zeckhauser, Principals and Agents: The Structure of Business. Boston: Harvard Business School Press, 1986, pp. 37-51

[13] J. Pavel and E. Beblava, "Transparentnost trhu verejneho obstaravania", Ekonomicky casopis, vol. 56, 2008, pp. 168-181.

[14] B. Merickova, J. Nemec and L. Vitek, "Contracting-out at Local Government level: Theory and Selected Evidence from Czech and Slovak Republics”, Public Management Review, vol. 7, 2005, no. 4, pp. 638-647.

[15] B. Merickova, J. Nemec, E. Sicakova Beblava and M. Beblavy, Kontrahovanie sluzieb vo verejnom sektore. Bratislava: Transparency International Slovensko, 2010.

[16] J. Nemec, B. Mikusova Merickova and Z. Vozarova, "Management of contracting public services and its quality in Slovakia", Journal of Public Administration and Policy, vol. 5, 1/2012, pp. 55-74.

[17] J. Pavel, "Efektivnost obecnich obchodnich spolecnosti pri poskytovani sluzeb", Politicka ekonomie, vol. 55, n. 5, 2007, pp. 681693.

[18] E. Hinloopen, P. Nijkamp and P. Rietveld, "The Regime Method: a New Multicriteria Method". In: P. Hansen, Essays and Surveys on Multiple Criteria Decision Making, Berlin: Springer, 1982, pp. 254285

[19] A. Charnes, W. W. Cooper and E. Rhodes, "Measuring the Efficiency of Decision Making Units", European Journal of Operational Research, vol. 2, n. 6, 1978, pp. 429-444.

[20] F. Ochrana and M. Nekola, "Economic evaluation of public programs", Ekonomicky casopis, vol. 57, no. 5, 2009, pp. 458-74.

[21] T. Zizka, "Technicko - ekonomicke hodnotenie vyrobkov metodami hodnotoveho inzinierstva", In: T. Zizka, Akost - pravo standardizacia, Banska Bystrica: DT ČSVTS, 1988, pp. 56-70.

[22] E. Löffler, "Defining Quality in Public Administration". In: Wright, G., Government, Market and the Civic Sector: The Search for a Productive Partnership. Bratislava: NISPAcee, 2001, pp. 67-80.

[23] M. Wisniewski, "Using SERVQUAL to Assess Customer Satisfaction with Public Sector Services", Managing Service Quality, vol. 11, n. 6, 2001, pp. 380-388.

[24] T. L. Saaty, L. G. Vargas and R. E. Wendell, "Assessing Attribute Weights by Rations", International Journal of Management Science, vol. 2, 1983, pp. 9-13. 